\title{
Influence of sowing date and organic fertilizers on productivity of Moringa oleifera plant under Aswan governorate conditions, Egypt
}

\author{
Mahmoud H. M. A. ${ }^{\text {a }}$ Hassan E. A. ${ }^{a^{*}}$, Aboelfetoh M. A. ${ }^{\mathrm{b}}$ \\ ${ }^{a}$ Department of Horticulture, Faculty of Agriculture, Al-Azhar University, Assiut, Egypt \\ ${ }^{b}$ Department of Horticulture Crops Technology, National Research Center, Giza, Egypt
}

\begin{abstract}
An experiment field were carried out in Aswan governorate, Egypt, during the two consecutive of seasons 20.17 and 2018 to evaluate the effect of organic fertilization and sowing date on: plant vegetation, yield and leaves chemical constituents of moringa plant. The organic fertilizers were farmyard manure (FYM), compost $(\mathrm{COM})$ and poultry manure (PM). The results showed that, generally, organic fertilization improved growth characters, yield as well as N, P and K percentages in leaves. Whereas, the highest N, P and K contents leave were recorded when poultry manure added at $10 \mathrm{~m}^{3}$ /feddan rate (feddan $=4200 \mathrm{~m}^{2}=0.420$ hectares $=$ 1.037 acres).
\end{abstract}

Keywords: moringa, sowing date, organic fertilizers, farmyard manure, compost, poultry manure. 


\section{Introduction}

Moringa oleifera is a fast-growing tree which belongs to the moringaceae family. It is one of the most importance traditional multipurpose food plants that is produced and used in many African countries (Amaglo et al., 2007). Moringa has a great potential to become one of the most economically important crops for the tropics and subtropics considering its use in many fields as a medicine (Peixoto et al., 2011), food (Pontual et al., 2012) and fodder plant. The demand for the plant products has been on ascendancy. However, not much work has been done on its cultivation especially in the various ecological zones. Organic fertilization deficiency limits the protections of many crops especially grain legumes in many soils. The application of farmyard manure to soil markedly increases plant growth availability of nutrients in soil and nutrients uptake by plants. Using the organic fertilizers to improved soil quality and fertility dates back to thousands of years ago. Greeks and Romans applied animal manure and human sewage to soil. At that time, they also knew that wheat took advantages if grown on fields previously cultivated with leguminous plants (Goss et al., 2013). Different materials, such as seashells, vegetable waste, farmyard manure and other waste products were already utilized to enhance crop growth. Nowadays the most common soil organic fertilizers are compost and animal manure and plant residues (Scotti et al., 2015). Both inorganic and organic substances can be added into the soil as soil amendments. Organic substances consist of material derived from living things (e.g. plants), whereas inorganic substances are mined or man-made (Bernal et al., 2009). Moringa can grow well under tropical and subtropical areas; however, fertilization needs to be investigated under the Egyptian conditions. This work aimed to investigate the response of Moringa oleifera to sowing date and some source organic fertilization on growth, yield and chemical constituents under upper Egypt conditions.

\section{Materials and methods}

An experiment was carried out in a private farm in Aswan governorate, Egypt, during the two consecutive seasons (2017 and 2018) to study the influence of sowing date and source organic fertilizer on growth, yield parameters and chemical constituents of moringa plants under upper Egypt conditions. The organic fertilizers were Farmyard manure (FYM), compost $(\mathrm{COM})$ and poultry manure (PM). The experimental plot was $2.0 \times 3.0 \mathrm{~m}$ having 5 rows at $60 \mathrm{~cm}$ apart with $25 \mathrm{~cm}$ hills distances in the row (40 plants/ plot). The approximate plant population was 24000 plants per feddan $\left(4200 \mathrm{~m}^{2}\right)$. The experiment was split plot design with three replicates. Moringa plants were sown three time on $1^{\text {st }}$ April, $15^{\text {th }}$ April and $1^{\text {st }}$ May of the two seasons. Chemical and physical analyses of soil were carried out according to Page et al. (1982) and Klute (1986). Some physical and chemical properties of the field experiment are presented in Table (1). 
Some chemical properties of used Farmyard manure and compost are shown in Table (2). Different levels of farmyard manure $\left(15\left(\mathrm{FYM}_{15}\right)\right.$ and 30 $\left(\mathrm{FYM}_{30}\right) \mathrm{m}^{3}$ /feddan) $\left(\right.$ feddan $=4200 \mathrm{~m}^{2}$ $=0.420$ hectares $=1.037$ acres), compost

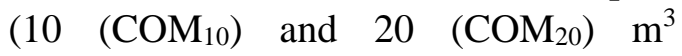
/feddan) and poultry manure $\left(5\left(\mathrm{PM}_{5}\right)\right.$ and $10\left(\mathrm{PM}_{10}\right) \mathrm{m}^{3} /$ feddan $)$ were mixed well with surface soil layes $(25 \mathrm{~cm})$ of the experimental farm. The following data were recorded at harvest stages for the three cuts. The first after two months of sowing date and next cut after first. Vegetative plant samples of moringa were randomly taken from each plot by cutting the plants $10-\mathrm{cm}$ above the soil surface. The plant samples were freshly weighed and then air dried until constant dry weight. Some morphological parameters were measured (plant height, branches No./plant as well as fresh and dry leaves yield as $\mathrm{kg}$ per feddan. Half gram of leaves plant was digested in 10 $\mathrm{ml}$ of $\mathrm{H}_{2} \mathrm{SO}_{4}$ and $2 \mathrm{ml}$ perchloric acid in a conical flask as described by Chapman and Pratt (1961). The digests samples were distilled using determined nitrogen $(\mathrm{N})$, phosphorus $(\mathrm{P})$ and potassium $(\mathrm{K})$ percentages in the dry leaves were determined as follows: $\mathrm{N}$ was determined according to the modified micro Kjeldahel method as described by Wildy et al. (1985), $\mathrm{P}$ was estimated colorimetrically according to the method of Chapman and Pratt (1975) and K was determined by Flame-photometer according to Cottenie et al. (1982).

Table (1): Some chemical properties of the experimental soil.

\begin{tabular}{|l|c|c|l|c|c|}
\hline Soil parameter & Unit & Values & Soil parameter & Unit & Values \\
\hline Sand & $(\mathrm{g} / \mathrm{kg})$ & 536.1 & O.M & $(\mathrm{g} / \mathrm{kg})$ & 15.1 \\
\hline Silt & $(\mathrm{g} / \mathrm{kg})$ & 221.9 & Total-N & $(\mathrm{g} / \mathrm{kg})$ & 0.9 \\
\hline Clay & $(\mathrm{g} / \mathrm{kg})$ & 242.0 & Total-P & $(\mathrm{g} / \mathrm{kg})$ & 0.8 \\
\hline Texture grade & ---- & Sandy Clay Loam & Total-K & $(\mathrm{g} / \mathrm{kg})$ & 0.1 \\
\hline $\mathrm{pH}(1: 2.5)$ & ----- & 7.81 & Ava-P & $(\mathrm{mg} / \mathrm{kg})$ & 13.50 \\
\hline EC $(1: 2.5)$ & $(\mathrm{dS} / \mathrm{m})$ & 1.321 & Ava-K & $(\mathrm{mg} / \mathrm{kg})$ & 129.51 \\
\hline
\end{tabular}

Table (2): Some chemical characteristics of the studied organic fertilization.

\begin{tabular}{|l|c|c|c|c|}
\hline Property & Unit & Farmyard manure & Compost & Poultry Manure \\
\hline $\mathrm{pH}(1: 2.5)$ & --- & 6.92 & 7.85 & 6.78 \\
\hline $\mathrm{EC}(1: 2.5)$ & $(\mathrm{dS} / \mathrm{m})$ & 1.69 & 2.88 & 2.96 \\
\hline $\mathrm{OM}$ & $(\%)$ & 35.80 & 37.95 & 55.51 \\
\hline $\mathrm{N}$ & $(\%)$ & 2.27 & 2.22 & 2.88 \\
\hline $\mathrm{P}$ & $(\%)$ & 1.29 & 1.33 & 1.65 \\
\hline $\mathrm{K}$ & $(\%)$ & 0.95 & 1.83 & 3.80 \\
\hline
\end{tabular}

\section{Results}

3.1 Effect of sowing date and some source organic fertilizers on vegetative growth moringa

Data presented in Figure (1) and Table (3) show that plant height and number of 
branches /plant were significantly increased in both seasons due to sowing date and some source organic fertilizers on vegetative growth. It is clear that the use of organic fertilizers at all levels led to a significant increment in plant height among all cuts at the two seasons as compared to control in most cases. Sowing date at $1^{\text {st }}$ April, compared with organic fertilizers treatment $\mathrm{FYM}_{15}$, $\mathrm{FYM}_{30}, \mathrm{COM}_{10}, \mathrm{COM}_{20}, \mathrm{PM}_{5}$ and $\mathrm{PM}_{10}$ increased plant height by 7.0, 12.6, $12.3,18.6,17.5$ and $26.7 \%$ in the first cut, by $3.6,9.6,8.3,13.5,15.5$ and $24.1 \%$ in the second cut and by 3.5, 8.0, 9.3, $13.5,17.3$ and $26.9 \%$ in the third cut over untreated ones in first season, respectively.

Table (3): The influence of sowing date and some source organic fertilization on number of branches of morinaga plants during the seasons of 2017and 2018.

\begin{tabular}{|c|c|c|c|c|c|c|c|c|}
\hline \multirow{4}{*}{ Fertilizer (B) } & \multicolumn{8}{|c|}{ Sowing date $(\mathrm{A})$} \\
\hline & $\begin{array}{c}1^{\text {st }} \text { time } \\
1 / 4\end{array}$ & $\begin{array}{c}2^{\text {nd }} \text { time } \\
15 / 4\end{array}$ & $\begin{array}{c}3^{\text {th }} \text { time } \\
1 / 5\end{array}$ & Mean & $\begin{array}{c}1^{\text {st }} \text { time } \\
1 / 4\end{array}$ & $\begin{array}{c}2^{\text {nd }} \text { time } \\
15 / 4\end{array}$ & $\begin{array}{c}3^{\text {th }} \text { time } \\
1 / 5\end{array}$ & Mean \\
\hline & \multicolumn{8}{|c|}{ First cut } \\
\hline & \multicolumn{4}{|c|}{ First season } & \multicolumn{4}{|c|}{ Second season } \\
\hline Control & 4.3 & 4.7 & 4.0 & 4.3 & 4.7 & 4.8 & 5.0 & 4.8 \\
\hline Farmyard manure $15 \mathrm{~m}^{3} /$ feddan & 5.0 & 5.0 & 4.7 & 4.9 & 5.0 & 5.2 & 5.0 & 5.1 \\
\hline Farmyard manure $30 \mathrm{~m}^{3} /$ feddan & 6.3 & 6.7 & 6.3 & 6.4 & 6.3 & 8.0 & 7.3 & 7.2 \\
\hline Compost $10 \mathrm{~m}^{3} /$ feddan & 5.0 & 5.0 & 4.7 & 4.9 & 5.0 & 5.3 & 5.0 & 5.1 \\
\hline Compost $20 \mathrm{~m}^{3} /$ feddan & 5.7 & 6.3 & 6.0 & 6.0 & 6.3 & 7.3 & 6.3 & 6.6 \\
\hline poultry manure $5 \mathrm{~m}^{3} /$ feddan & 5.0 & 5.7 & 5.7 & 5.5 & 6.3 & 6.3 & 6.7 & 6.4 \\
\hline poultry manure $10 \mathrm{~m}^{3} /$ feddan & 7.0 & 5.7 & 6.3 & 6.3 & 7.7 & 6.3 & 8.3 & 7.4 \\
\hline Mean & 5.5 & 5.6 & 5.4 & 5.5 & 5.9 & 6.2 & 6.2 & 6.1 \\
\hline \multirow[t]{2}{*}{ L.S.D. for $5 \%$} & \multicolumn{2}{|c|}{ A: NS $\quad$ B: } & \multicolumn{2}{|c|}{$52 \quad \mathrm{~A}^{*} \mathrm{~B}: \mathrm{NS}$} & \multicolumn{2}{|c|}{ A:0.507 $\quad$ B: 0} & \multicolumn{2}{|c|}{$\mathrm{A} * \mathrm{~B}: \mathrm{NS}$} \\
\hline & \multicolumn{8}{|c|}{ Second cut } \\
\hline Control & 5.8 & 6.0 & 5.0 & 5.6 & 5.7 & 6.0 & 5.8 & 5.8 \\
\hline Farmyard manure $15 \mathrm{~m}^{3} /$ feddan & 6.2 & 6.7 & 6.0 & 6.3 & 5.7 & 6.7 & 6.2 & 6.2 \\
\hline Farmyard manure $30 \mathrm{~m}^{3} /$ feddan & 8.3 & 9.3 & 9.0 & 8.9 & 8.7 & 10.0 & 9.0 & 9.2 \\
\hline Compost $10 \mathrm{~m}^{3} /$ feddan & 6.0 & 6.0 & 5.7 & 5.9 & 6.7 & 6.0 & 6.0 & 6.2 \\
\hline Compost $20 \mathrm{~m}^{3} /$ feddan & 8.0 & 8.3 & 7.7 & 8.0 & 8.3 & 9.0 & 8.7 & 8.7 \\
\hline poultry manure $5 \mathrm{~m}^{3} /$ feddan & 6.7 & 7.7 & 7.7 & 7.4 & 8.0 & 8.0 & 8.7 & 8.2 \\
\hline poultry manure $10 \mathrm{~m}^{3} /$ feddan & 11.0 & 7.3 & 11.0 & 9.8 & 11.0 & 7.7 & 11.7 & 10.1 \\
\hline Mean & 7.4 & 7.3 & 7.4 & 7.4 & 7.7 & 7.6 & 8.0 & 7.8 \\
\hline \multirow[t]{2}{*}{ L.S.D. for $5 \%$} & \multicolumn{2}{|c|}{ 1. A: 0.575} & \multicolumn{2}{|c|}{$\begin{array}{ll}78 & \mathrm{~A} * \mathrm{~B}: \mathrm{NS} \\
\end{array}$} & \multicolumn{2}{|c|}{ 2. A:0.528 B } & \multicolumn{2}{|c|}{$6 \quad \mathrm{~A} * \mathrm{~B}: \mathrm{NS}$} \\
\hline & \multicolumn{8}{|c|}{ Third cut } \\
\hline Control & 7.0 & 7.0 & 6.0 & 6.7 & 7.2 & 7.3 & 7.2 & 7.2 \\
\hline Farmyard manure $15 \mathrm{~m}^{3} /$ feddan & 7.3 & 7.7 & 7.3 & 7.4 & 7.5 & 7.5 & 7.6 & 7.5 \\
\hline Farmyard manure $30 \mathrm{~m}^{3} /$ feddan & 9.0 & 10.0 & 10.0 & 9.7 & 9.3 & 11.3 & 10.3 & 10.3 \\
\hline Compost $10 \mathrm{~m}^{3} /$ feddan & 7.3 & 7.7 & 7.0 & 7.3 & 7.3 & 7.0 & 7.0 & 7.1 \\
\hline Compost $20 \mathrm{~m}^{3} /$ feddan & 8.7 & 9.7 & 8.3 & 8.9 & 9.3 & 10.0 & 9.3 & 9.5 \\
\hline poultry manure $5 \mathrm{~m}^{3} /$ feddan & 7.7 & 8.3 & 8.3 & 8.1 & 8.7 & 9.3 & 9.7 & 9.2 \\
\hline poultry manure $10 \mathrm{~m}^{3} /$ feddan & 12.3 & 8.3 & 12.3 & 11.0 & 11.7 & 8.7 & 12.0 & 10.8 \\
\hline Mean & 8.5 & 8.4 & 8.5 & 8.4 & 8.7 & $\begin{array}{r}8.7 \\
\end{array}$ & 9.0 & 8.8 \\
\hline L.S.D. for $5 \%$ & A:0.519 & B: 0.793 & $\mathrm{~A} * \mathrm{~B}: \mathrm{NS}$ & & $\mathrm{A}: 0.403$ & B:0.616 & B: 1.067 & \\
\hline
\end{tabular}

While, organic fertilizers treatment $\mathrm{FYM}_{15}, \mathrm{FYM}_{30}, \mathrm{COM}_{10}, \mathrm{CO}_{20}, \mathrm{PM}_{5}$ and $\mathrm{PM}_{10}$ increased plant height by $6.9,10.4$, $10.8,14.9,17.4$ and $27.1 \%$ in the first cut, by $4.3,9.5,8.9,12.5,13.5$ and $24.3 \%$ in the second cut and by $5.9,11.1,9.8$, 14.0,18.9 and $26.1 \%$ in the third cut over untreated ones in second season. 

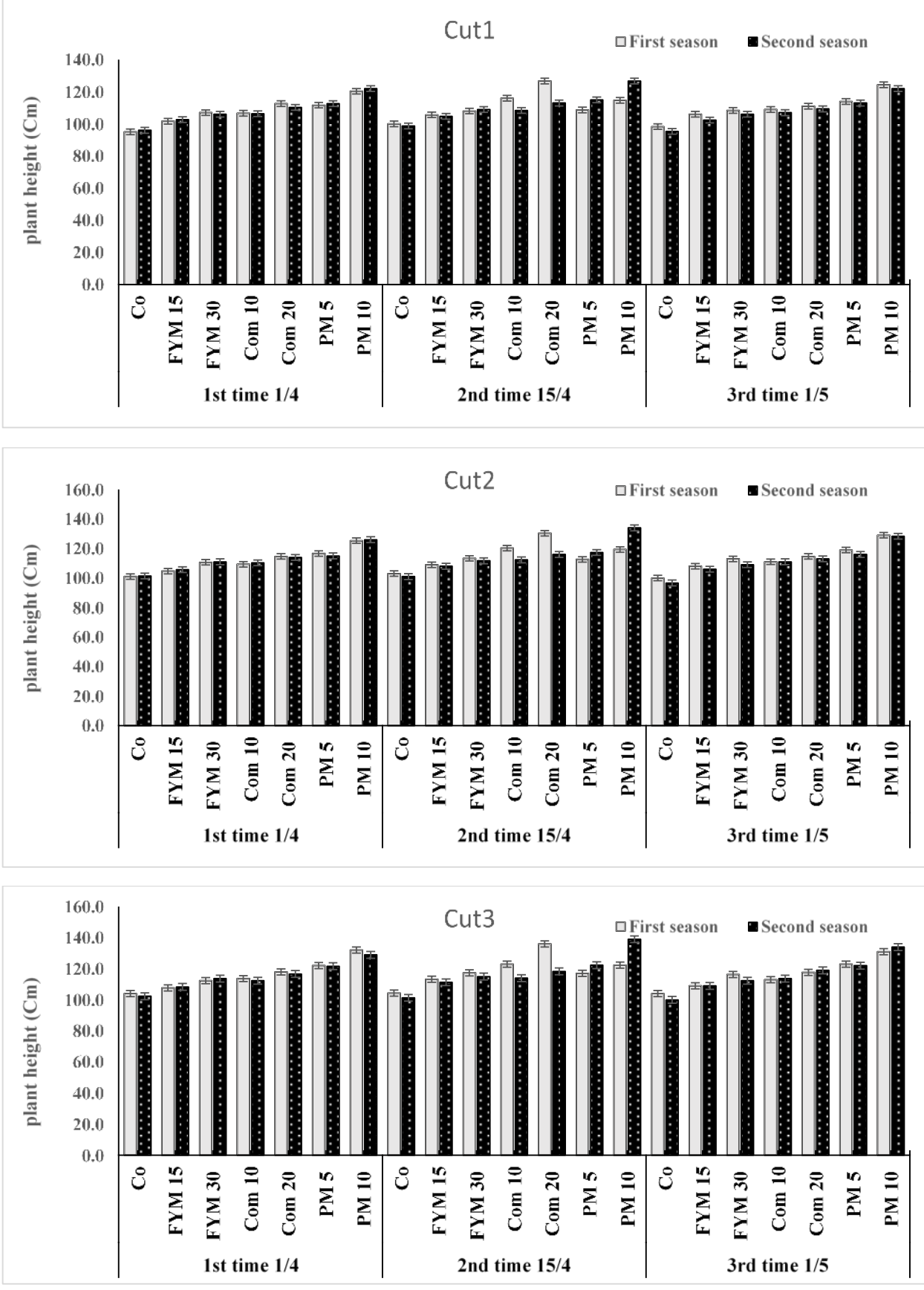

Figure (1): The influence of sowing date and some source organic fertilization on plant height $(\mathrm{cm})$ of morinaga plants during the seasons of 2017and 2018. 
It is clear that the sowing date led to a significant increment in plant height among all cuts at the two seasons as compared to control. In most cases, the highest value of the plant height was observed of after the harvest of plants with applying $\mathrm{PM}_{10}(139.0 \mathrm{~cm})$ for third cut and $1^{\text {st }}$ May in second season, and $\mathrm{Com}_{20}(136.0 \mathrm{~cm})$ for third cut and $15^{\text {th }}$ April in first season. On the other hand, the lowest value of plant height was observed of after the harvest of plants with applying Co $(95.0 \mathrm{~cm}$ ) for first cut and $1^{\text {st }}$ April in first seasons, and Co $(96.0 \mathrm{~cm})$ for first cut and $1^{\text {st }}$ April in second season. Data listed in Table (3) reveal that the main effect of sowing date and some source organic fertilizers treatments on branch number of Moringa plants was statistically significant at the three cuts for the second seasons. All organic fertilizers treatments led to a significant increase in branch number among all cuts compared to unfertilized control in the two seasons in most cases.

\subsection{Effect of sowing date and some source organic fertilizers on moringa yield}

The obtained data pointed out that fresh and dry weight ( $\mathrm{kg} /$ feddan) of moringa was significantly affected by supplying the plants with sowing date and some source organic fertilizers at the three cuts for the two seasons (Table 4 and Figure 2).

Table (4): The influence of sowing date and some source organic fertilization on yield fresh leaves ( $\mathrm{kg} /$ feddan) of Morinaga plants during the seasons of 2017 and 2018.

\begin{tabular}{|c|c|c|c|c|c|c|c|c|}
\hline \multirow{4}{*}{ Fertilizer (B) } & \multicolumn{8}{|c|}{ Sowing date $(\mathrm{A})$} \\
\hline & $1^{\text {st }}$ time $1 / 4$ & $2^{\text {nd }}$ time $15 / 4$ & $3^{\text {th }}$ time $1 / 5$ & Mean & $1^{\text {st }}$ time $1 / 4$ & $2^{\text {nd }}$ time $15 / 4$ & $3^{\text {th }}$ time $1 / 5$ & Mean \\
\hline & \multicolumn{8}{|c|}{ First cut } \\
\hline & \multicolumn{4}{|c|}{ First season } & \multicolumn{4}{|c|}{ Second season } \\
\hline Control & 280.0 & 304.0 & 328.0 & 304.0 & 368.0 & 360.0 & 360.0 & 362.7 \\
\hline Farmyard manure $15 \mathrm{~m}^{3} /$ feddan & 320.0 & 368.0 & 400.0 & 362.7 & 408.0 & 432.0 & 408.0 & 416.0 \\
\hline Farmyard manure $30 \mathrm{~m}^{3} / \mathrm{feddan}$ & 560.0 & 648.0 & 616.0 & 608.0 & 624.0 & 680.0 & 584.0 & 629.3 \\
\hline Compost $10 \mathrm{~m}^{3} /$ feddan & 360.0 & 400.0 & 384.0 & 381.3 & 400.0 & 424.0 & 408.0 & 410.7 \\
\hline Compost $20 \mathrm{~m}^{3} /$ feddan & 584.0 & 624.0 & 616.0 & 608.0 & 576.0 & 592.0 & 576.0 & 581.3 \\
\hline poultry manure $5 \mathrm{~m}^{3} /$ feddan & 568.0 & 656.0 & 600.0 & 608.0 & 504.0 & 576.0 & 552.0 & 544.0 \\
\hline poultry manure $10 \mathrm{~m}^{3} /$ feddan & 784.0 & 520.0 & 688.0 & 664.0 & 784.0 & 520.0 & 744.0 & 682.7 \\
\hline Mean & 493.7 & 502.9 & 518.9 & 505.1 & 523.4 & 512.0 & 518.9 & 518.1 \\
\hline \multirow[t]{2}{*}{ L.S.D. for $5 \%$} & \multicolumn{4}{|c|}{$\mathrm{B}: 11.595 \mathrm{~A} * \mathrm{~B}: 20.083$} & $\mathrm{~A}: 17.797$ & \multicolumn{3}{|c|}{$\mathrm{B}: 27.185 \quad \mathrm{~A} * \mathrm{~B}: 47.086$} \\
\hline & \multicolumn{8}{|c|}{ Second cut } \\
\hline Control & 408.0 & 456.0 & 424.0 & 429.3 & 504.0 & 512.0 & 496.0 & 504.0 \\
\hline Farmyard manure $15 \mathrm{~m}^{3} /$ feddan & 496.0 & 528.0 & 552.0 & 525.3 & 560.0 & 600.0 & 544.0 & 568.0 \\
\hline Farmyard manure $30 \mathrm{~m}^{3}$ /feddan & 752.0 & 824.0 & 768.0 & 781.3 & 816.0 & 864.0 & 752.0 & 810.7 \\
\hline Compost $10 \mathrm{~m}^{3} /$ feddan & 544.0 & 552.0 & 544.0 & 546.7 & 552.0 & 576.0 & 528.0 & 552.0 \\
\hline Compost $20 \mathrm{~m}^{3} /$ feddan & 752.0 & 792.0 & 784.0 & 776.0 & 744.0 & 744.0 & $\frac{3.0 .0}{720.0}$ & 736.0 \\
\hline poultry manure $5 \mathrm{~m}^{3} /$ feddan & 784.0 & 816.0 & 768.0 & 789.3 & 664.0 & 744.0 & 736.0 & 714.7 \\
\hline poultry manure $10 \mathrm{~m}^{3} /$ feddan & 912.0 & 680.0 & 904.0 & 832.0 & 936.0 & 672.0 & 928.0 & 845.3 \\
\hline Mean & 664.0 & 664.0 & 677.7 & 668.6 & 682.3 & 673.1 & 672.0 & 675.8 \\
\hline \multirow[t]{2}{*}{ L.S.D. for $5 \%$} & \multicolumn{4}{|c|}{$\mathrm{B}: 14.230 \quad \mathrm{~A} * \mathrm{~B}: 24.647$} & \multicolumn{4}{|c|}{ A:18.492 $\quad$ B:28.248 $\quad$ A*B:48.927 } \\
\hline & \multicolumn{8}{|c|}{ Third cut } \\
\hline Control & 448.0 & 512.0 & 480.0 & 480.0 & 536.0 & 552.0 & 544.0 & 544.0 \\
\hline Farmyard manure $15 \mathrm{~m}^{3} /$ feddan & 520.0 & 584.0 & 584.0 & 562.7 & 600.0 & 632.0 & 584.0 & 605.3 \\
\hline Farmyard manure $30 \mathrm{~m}^{3} /$ feddan & 792.0 & 840.0 & 808.0 & 813.3 & 848.0 & 896.0 & 792.0 & 845.3 \\
\hline Compost $10 \mathrm{~m}^{3} /$ feddan & 608.0 & 600.0 & 576.0 & 594.7 & 592.0 & 608.0 & 576.0 & 592.0 \\
\hline Compost $20 \mathrm{~m}^{3} /$ feddan & 784.0 & 808.0 & 824.0 & 805.3 & 792.0 & 784.0 & 760.0 & 778.7 \\
\hline poultry manure $5 \mathrm{~m}^{3} /$ feddan & 832.0 & 848.0 & 792.0 & 824.0 & 704.0 & 784.0 & 776.0 & 754.7 \\
\hline poultry manure $10 \mathrm{~m}^{3} /$ feddan & 960.0 & 712.0 & 952.0 & 874.7 & 960.0 & 712.0 & 984.0 & 885.3 \\
\hline Mean & 706.3 & 700.6 & 716.6 & 707.8 & 718.9 & 709.7 & 716.6 & 715.0 \\
\hline L.S.D. for $5 \%$ & A:9.258 & $14.142 \mathrm{~A} * \mathrm{~B}: 2$ & & & A:17.902 & $\mathrm{B}: 27.345 \quad \mathrm{~A} * \mathrm{~B}:$ & .363 & \\
\hline
\end{tabular}



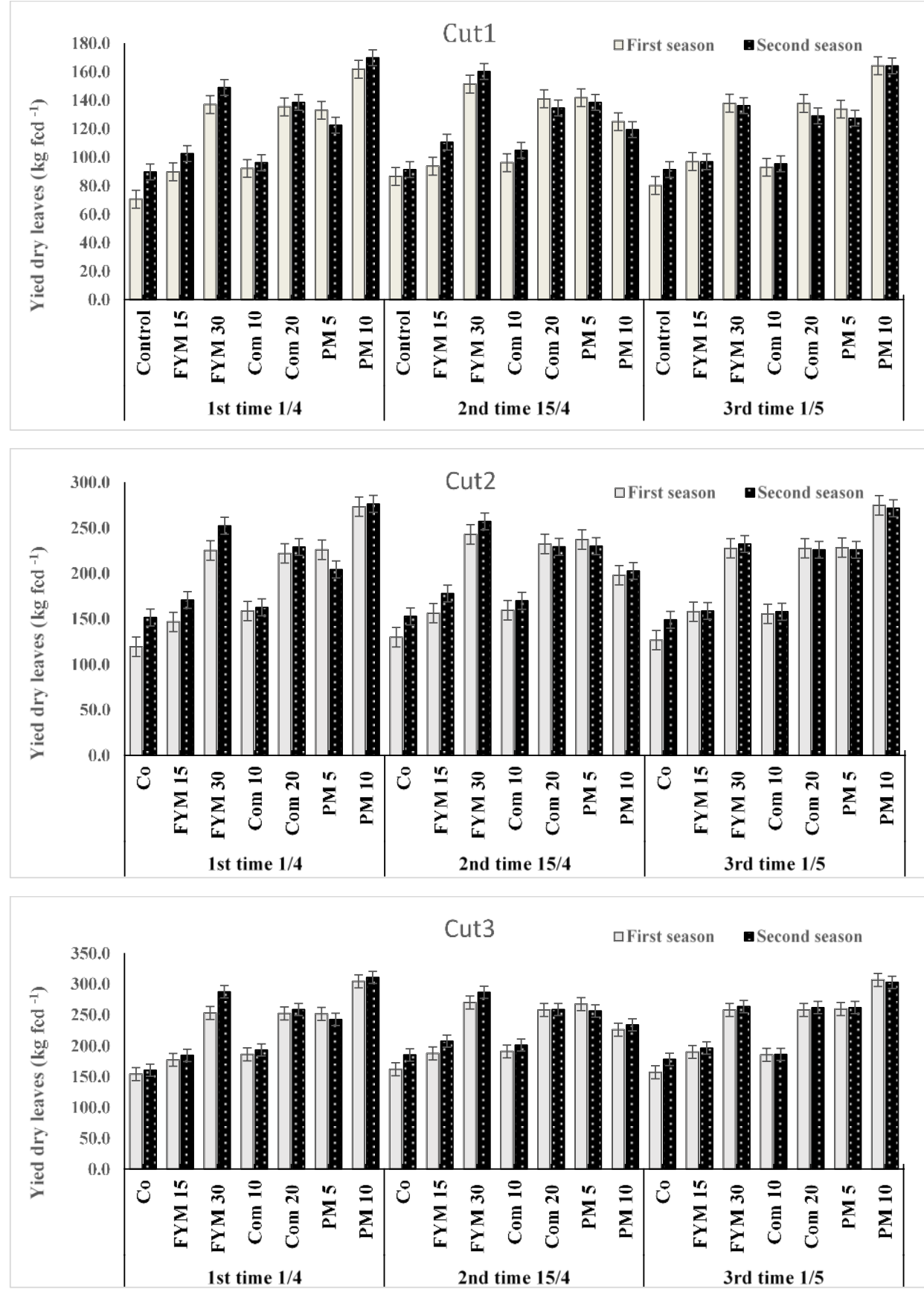

Figure (2): The influence of sowing date and some source organic fertilization on yield dry leaves ( $\mathrm{kg} /$ feddan) of moringa plants during the seasons of 2017 and 2018. 
Sowing date 1 Apirl, organic fertilizers treatment $\mathrm{FYM}_{15}, \mathrm{FYM}_{30}, \mathrm{COM}_{10}$, $\mathrm{COM}_{20}, \mathrm{PM}_{5}$ and $\mathrm{PM}_{10}$ increased yield dry leaves by $27.3,94.3,30.7,92.0,88.6$ and $129.5 \%$ in the first cut, by $22.8,88.6$, $32.9,85.9,89.3$ and $128.9 \%$ in the second cut and by 15.1, 64.6, 20.8, 64.1,63.5 and $97.9 \%$ in the third cut over untreated ones in first season, respectively. While organic fertilizers treatment $\mathrm{FYM}_{15}$, $\mathrm{FYM}_{30}, \mathrm{COM}_{10}, \mathrm{COM}_{20}, \mathrm{PM}_{5}$ and $\mathrm{PM}_{10}$ increased yield dry leaves by $14.3,66.1$, $7.1,54.5,36.6$ and $89.3 \%$ in the first cut, by $12.7,66.7,7.4,51.3,34.9$ and $82.5 \%$ in the second cut and by 15.0, 79.5, 20.5,
61.5, 51.5 and $94.0 \%$ in the third cut over untreated ones in second season.

3.3 Effect of sowing date and some source organic fertilizers on moringa chemical constituents

It was noticed that, $\mathrm{N}, \mathrm{P}$ and $\mathrm{K}$ percentage gradually increased, while a significant in both experimental seasons with increasing organic fertilizers level (Table 5). The highest $\mathrm{N}(4.73 \%), \mathrm{P}$ $(0.20 \%)$ and $\mathrm{K}(1.67 \%)$ percentage were recorded when poultry manure $10 \mathrm{~m}^{3}$ /feddan.

Table (5): The influence of sowing date and some source organic fertilization on nitrogen $(\mathrm{N})$, phosphorus (P) and potassium (K) (\%) of morinaga plants during the seasons of 2017and 2018.

\begin{tabular}{|c|c|c|c|c|c|c|c|c|}
\hline \multirow{4}{*}{ Fertilizer (B) } & \multicolumn{8}{|c|}{ Sowing date (A) } \\
\hline & $1^{\text {st }}$ time $1 / 4$ & $2^{\text {nd }}$ time $15 / 4$ & $3^{\text {th }}$ time $1 / 5$ & Mean & $1^{\text {st }}$ time $1 / 4$ & $2^{\text {nd }}$ time $15 / 4$ & $3^{\text {th }}$ time $1 / 5$ & Mean \\
\hline & \multicolumn{8}{|c|}{ Nitrogen $(\mathrm{N})$} \\
\hline & \multicolumn{4}{|c|}{ First season } & \multicolumn{4}{|c|}{ Second season } \\
\hline Control & 1.15 & 1.86 & 1.47 & 1.49 & 1.20 & 1.90 & 1.52 & 1.54 \\
\hline Farmyard manure $15 \mathrm{~m}^{3} /$ feddan & 3.63 & 3.70 & 3.33 & 3.56 & 3.50 & 3.83 & 4.00 & 3.78 \\
\hline Farmyard manure $30 \mathrm{~m}^{3} /$ feddan & 4.23 & 4.05 & 4.00 & 4.09 & 4.53 & 4.20 & 4.20 & 4.31 \\
\hline Compost $10 \mathrm{~m}^{3} /$ feddan & 2.67 & 2.87 & 2.77 & 2.77 & 3.80 & 3.27 & 4.07 & 3.71 \\
\hline Compost $20 \mathrm{~m}^{3} /$ feddan & 3.93 & 3.63 & 4.00 & 3.86 & 4.33 & 3.70 & 4.17 & 4.07 \\
\hline poultry manure $5 \mathrm{~m}^{3} /$ feddan & 3.60 & 4.23 & 4.07 & 3.97 & 3.53 & 4.50 & 4.10 & 4.04 \\
\hline poultry manure $10 \mathrm{~m}^{3} /$ feddan & 4.73 & 3.06 & 5.00 & 4.26 & 6.00 & 3.10 & 5.33 & 4.81 \\
\hline Mean & 3.42 & 3.34 & 3.52 & 3.43 & 3.84 & 3.50 & 3.91 & 3.75 \\
\hline \multirow[t]{2}{*}{ L.S.D. for $5 \%$} & A: 0.118 & B:0.181 $\quad \mathrm{A} * \mathrm{~B}: \mathrm{C}$ & & & A:NS & $0.230 \quad \mathrm{~A}^{*} \mathrm{~B}$ & 398 & \\
\hline & \multicolumn{8}{|c|}{ Phosphorus (P) } \\
\hline Control & 0.07 & 0.09 & 0.03 & 0.05 & 0.10 & 0.06 & 0.04 & 0.10 \\
\hline Farmyard manure $15 \mathrm{~m}^{3} /$ feddan & 0.10 & 0.05 & 0.05 & 0.07 & 0.13 & 0.07 & 0.07 & 0.09 \\
\hline Farmyard manure $30 \mathrm{~m}^{3} /$ feddan & 0.13 & 0.09 & 0.10 & 0.10 & 0.16 & 0.12 & 0.10 & 0.13 \\
\hline Compost $10 \mathrm{~m}^{3} /$ feddan & 0.11 & 0.05 & 0.08 & 0.08 & 0.12 & 0.09 & 0.10 & 0.10 \\
\hline Compost $20 \mathrm{~m}^{3} /$ feddan & 0.20 & 0.14 & 0.09 & 0.14 & 0.21 & 0.15 & 0.12 & 0.16 \\
\hline poultry manure $5 \mathrm{~m}^{3} /$ feddan & 0.14 & 0.09 & 0.09 & 0.11 & 0.16 & 0.10 & 0.10 & 0.12 \\
\hline poultry manure $10 \mathrm{~m}^{3} /$ feddan & 0.20 & 0.12 & 0.18 & 0.16 & 0.21 & 0.14 & 0.13 & 0.16 \\
\hline Mean & 0.13 & 0.09 & 0.09 & 0.10 & 0.16 & 0.10 & 0.09 & 0.12 \\
\hline \multirow[t]{2}{*}{ L.S.D. for $5 \%$} & A:0.010 & B:0.015 $\quad \mathrm{A}^{*} \mathrm{~B}: 0$. & & & A:0.009 & $0.014 \quad \mathrm{~A}^{*} \mathrm{~B}: 0.0$ & & \\
\hline & \multicolumn{8}{|c|}{ Potassium $(\mathrm{K})$} \\
\hline Control & 1.16 & 1.04 & 1.09 & 1.10 & 1.22 & 1.07 & 1.08 & 1.12 \\
\hline Farmyard manure $15 \mathrm{~m}^{3} /$ feddan & 1.18 & 1.15 & 1.09 & 1.14 & 1.20 & 1.15 & 1.12 & 1.16 \\
\hline Farmyard manure $30 \mathrm{~m}^{3} /$ feddan & 1.38 & 1.31 & 1.32 & 1.33 & 1.40 & 1.32 & 1.35 & 1.36 \\
\hline Compost $10 \mathrm{~m}^{3} /$ feddan & 1.17 & 1.15 & 1.09 & 1.14 & 1.20 & 1.19 & 1.10 & 1.16 \\
\hline Compost $20 \mathrm{~m}^{3} /$ feddan & 1.51 & 1.54 & 1.42 & 1.49 & 1.53 & 1.58 & 1.43 & 1.51 \\
\hline poultry manure $5 \mathrm{~m}^{3} /$ feddan & 1.21 & 1.24 & 1.19 & 1.22 & 1.23 & 1.28 & 1.20 & 1.24 \\
\hline poultry manure $10 \mathrm{~m}^{3} /$ feddan & 1.64 & 1.38 & 1.64 & 1.55 & 1.68 & 1.41 & 1.89 & 1.66 \\
\hline Mean & 1.32 & 1.26 & 1.26 & 1.28 & 1.35 & 1.29 & 1.31 & 1.32 \\
\hline L.S.D. for $5 \%$ & A:0.015 & B:0.024 A*B: & & & A:0.013 & $3: 0.020 \quad A * B: 0$ & & \\
\hline
\end{tabular}




\section{Discussion}

The increase was gradual by the gradual increase in organic fertilizer levels. Organic fertilizers increased soil organic matter, improving physical, chemical and biological functions of the soil (Babalola et al., 2012). As it plays a crucial role in maintaining soil functions and is a parameter for soil fertility and resistance to erosion. Physical functions increasing SOM will enhance aggregation and stability and thereby improving soil structure and soil porosity. Stability of aggregates prevents surface sealing and soil erosion, improves water infiltration, and enhances water holding capacity (Martínez-Blanco et al., 2013). However, SOM improves the retention of plant nutrients and increases the soil biodiversity (Vanlauwe et al., 2015). As a chemical function it considered a source of plant nutrients, especially in the direct supply of N, P, S and K, enhance CEC particularly in soils. Similar results were found by Imoro et al. (2012), Pahla et al. (2013) and Umar (2014) on moringa. The micro-organisms require $\mathrm{N}$ for their growth, so they break down the organic materials and release nutrients. This process involves immobilization of $\mathrm{N}$ from the soil by the micro-organisms (Das and Deka, 2021). However, Geng et al. (2019) found that application of different composted organic residues significantly increased the $\mathrm{N}, \mathrm{P}$ and $\mathrm{K}$ uptake by corn plants over control and the increase was proportional to the increase in the composted organic residues rates. The uptake of macro and micronutrients were increased after application of bio-compost and application of different rates of farmyard manure are significantly effective in increasing most of absorbed macro and micronutrients by different parts of plant (Bayu et al., 2006). Rekaby et al. (2020) found that the uptake of $\mathrm{N}, \mathrm{P}$, and $\mathrm{K}$ nutrients in barley plants increased with applying of organic absorbents. Applying organic fertilizer to the soil can either increase metal availability, solubility, and plant uptake (Rekaby et al., 2020). Insoluble OM usually forms insoluble organ metal complexes, making them less available for plant uptake or leaching (Lal and Francaviglia, 2019). However, many organic fertilizers have a soluble $\mathrm{C}$ component or produce soluble decomposition products, which can increase metal solubility by forming soluble organ metal complexes. Micronutrients are also released through the biodegradation of OM by microorganisms (Kalantary et al., 2014).

\section{References}

Amaglo, N. K., Timpo, G. M., Ellis, W.O. and Bennett, R. N. (2007), "Effect of spacing and harvest frequency on the growth and leaf yield of moringa (Moringa oleifera Lam.), a leafy vegetable crop", Ghana Journal of Horticulture, Vol. 6, pp 33-40. 
Babalola, O. A., Adesodun, J. K., Olasantan, F. O. and Adekunle, A. F. (2012), "Responses of some soil biological, chemical and physical properties to short-term compost amendment", International Journal of Soil Science, Vol. 7 No. 1, pp. 28.

Bayu, W., Rethman, N. F. G., Hammes, P. S. and Alemu, G. (2006), "Effects of farmyard manure and inorganic fertilizers on sorghum growth, yield, and nitrogen use in a semi-arid area of Ethiopia", Journal of Plant Nutrition, Vol. 29, pp391-407.

Bernal M. P., Alburquerque, J. A. and Moral, R. (2009), "Composting of animal manures and chemical criteria for compost maturity assessment, A review", Bioresource Technology, Vol. 100, pp. 54445453.

Chapman, H. D. and Partt, P. F. (1961), Methods of analysis for soil, plants and water, University of California, Berkely, CA, USA.

Chpman, H. D. and Pratt, P. F. (1975), Methods of Analysis for Soil, Plant and Water, University of California, Berkely, CA, USA, pp. 172-174.

Cottenie, A., Verloo, M., Velghe, M. and Camerlynck, R. (1982), Chemical Analysis of Plant and Soil, Laboratory of Analytical and Ayro Chemistry, State University of Ghent, Belgium.

Das, D. and Deka, H. (2021), "Vermicomposting of harvested waste biomass of potato crop employing Eisenia fetida: changes in nutrient profile and assessment of the maturity of the end products", Environmental Science and Pollution Research, pp. 1-11.

Geng, Y., Cao, G., Wang, L. and Wang, S. (2019), "Effects of equal chemical fertilizer substitutions with organic manure on yield, dry matter, and nitrogen uptake of spring maize and soil nitrogen distribution", PloS ONE, Vol. 14 No. 7, e0219512.

Goss, M.J., Tubeileh, A. and Goorahoo, D. (2013) "A review of the use of organic amendments and the risk to human health", Advances in Agronomy, Vol. 120, pp. 275-379.

Imoro, A. W. M., Sackey, I. and Abubakar, A. H. (2012), "Preliminary study on the effects of two different sources of organic manure on the growth performance of Moringa oleifera seedlings", Journal of Biology, Agriculture and Healthcare, Vol. 2 No. 10, pp. 147158.

Kalantary, R. R., Mohseni-Bandpi, A., Esrafili, A., Nasseri, S., Ashmagh, F. R., Jorfi, S. and Ja'fari, M. (2014), "Effectiveness of biostimulation through nutrient content on the bioremediation of phenanthrene contaminated soil", Journal of Environmental Health Science and Engineering, Vol. 12 No. 1, pp. 1-9.

Klute, A. (1986), "Methods of Soil 
Analysis Part 1", Physical and Mineralogical Methods, $2^{\text {nd }}$ Ed., American Society of Agronomy Monograph No. 9, Madison, Wisconsin, USA.

Lal, R. and Francaviglia, R. (2019), "Sustainable soil management: Preventive and ameliorative strategies", Sustainable Agriculture Reviews, Vol. 29, Springer Nature Switzerland.

Martínez-Blanco, J., Lazcano, C., Christensen, T.H., Muñoz, P., Rieradevall, J., Møller, J., Antón, A. and Boldrin, A. (2013), Compost benefits for agriculture evaluated by life cycle assessment. A review. Agronomy for sustainable development, Vol. 33 No. 4, pp. 721-732.

Page, A. I., Miller, R. H. and keeney, D. R. (1982), Methods of Soil Analysis Part 2: Chemical and Microbiological Properties, $2^{\text {nd }}$ ed., American Society of Agronomy, Madison, Wisconsin, USA.

Pahla, I., Tagwira, F., Muzemu, S. and Chitamba, J. (2013), "Effects of soil type and manure level on the establishment and growth of Moringa oleifera", International Journal of Agriculture and Forestry, Vol. 3 No. 6, pp. 226-230.

Peixoto, R., Silva, G. C., Costa, R. A., Joseí, L. S., Vieira, G. H. F., Filho, A. A. F. and Vieira, H. S. F. (2011), "In vitro antibacterial effect of aqueous and ethanolic Moringa leaf extracts", Asian Pacific Journal of Tropical Medicine, Vol. 4 No. 3, pp. 201-204.

Pontual, V. E., Belany, E. A. C., Bezerra, S. R., Coelho, C. B., Napoleão, H. T. and Paiva, M. G. P. (2012), "Caseinolytic and milk-clotting activities from Moringa oleifera flowers", Food Chemistry, Vol. 135 No. 3-1, pp. 1848-1854.

Rekaby, S. A., Awad, M. Y., Hegab, S. A. and Eissa, M. A. (2020), "Effect of some organic amendments on barley plants under saline condition", Journal of Plant Nutrition, Vol.43 No. 12, pp. 1840 1851

Scotti, R., Ascoli, R. D., Bonanomi, G., Caceres, M. G., Sultana, S., Cozzolino, L., Scelza, R., Zoina, A. and Rao, M. A. (2015), "Combined use of compost and wood scraps to increase carbon stock and improve soil quality in intensive farming systems", Eur. J. Soil Sci., Vol. 66 No. 3, pp. 463-475.

Umar, A. F. (2014), "Effect of farm-yard manure and inorganic fertilizer application on the coppicing ability of Moringa oleifera (Lam.) plantation at Gaya, Kano, Nigeria", Umar, World J. Biol. Med. Science, Vol. 1 No. 2, pp. 37-45.

Vanlauwe, B., Descheemaeker, K., Giller, K. E., Huising, J., Merckx, R., Nziguheba, G., Wendt, J. and Zingore, S. (2015), "Integrated soil fertility management in sub-Saharan 
Mahmoud et al. / Archives of Agriculture Sciences Journal 4(1) 54-65, 2021.

Africa: unravelling local adaptation", Soil, Vol. 1 No. 1, pp. 491-508.

Wildy, S. A., Covey, R. P., Lyer, J. C. and Vodit, G. K. (1985), Soil and Plant Analysis for Tree Culture, Oxford and IBH Publishing Co., New Delhi, India. 